DEPARTMENT OF THE INTERIOR

U.S. GEOLOGICAL SURVEY

Trends of Heavy 0il Production in California

by Christopher J. Schenk ${ }^{1}$

Open-File Report 91-339

This report is preliminary and has not been reviewed for conformity with U.S Geological Survey editorial standards and stratigraphic nomenclature. Any use of trade, product, or firm names is for descriptive purposes only and does not imply endorsement by the U.S. Government.

${ }^{1}$ U.S. Geological Survey, MS 971, Box 25046, Denver, Colorado 80225 


\title{
Trends of Heavy 0il Production in California
}

\begin{abstract}
More heavy oil than light oil has been produced daily in California since 1972, to where today heavy oil constitutes about $70 \%$ of the daily production. Production of light oil in California peaked in 1954. The production of heavy oil is largely the result of steam-assisted recovery, as about half of the daily California petroleum production is brought about by steam injection. More heavy oil is produced in California than other States because a tremendous heavy oil resource is concentrated in several giant fields, in shallow reservoirs that are amenable to secondary and enhanced recovery techniques.
\end{abstract}

\section{Introduction}

As finding rates for conventional oil continue to decrease, the role of heavy oil in the U.S. energy mix will continue to gain in importance. Compilations of heavy oil resources in the U.S. show that most heavy oil is in California and Alaska, with relatively smaller amounts in Wyoming, Texas, Louisiana, and Arkansas (Kuuskraa and Godec, 1989). Most recoverable heavy oil at present is in California. The purpose of this paper is to illustrate production trends of heavy oil in California, as produced heavy oil is included in assessments of U.S. petroleum resources by the USGS. California compiles production data by oil gravity (Conservation Committee of California 0il Producers [CCCOP], 1990), which makes the State a good area to observe trends in heavy oil production.

\section{Definitions}

Crude oil is classified as light, heavy, or extra heavy (Meyer and de Witt, 1990). Viscosity is the accepted parameter with which to categorize an oil. Viscosities at reservoir temperature of less than 10,000 centipoises ( $(\mathrm{P})$ are used to distinguish heavy and extra heavy oil from natural asphalts, which exhibit viscosities greater than $10,000 \mathrm{cP}$ at reservoir temperature. API gravity is commonly used to divide heavy and extra heavy oil. Heavy oils have gravities from 10 to 20 API degrees, inclusive, whereas extra heavy oils have gravities less than 10 API degrees; light oils have gravities greater than 20 API degrees (Meyer and de Witt, 1990). Natural asphalts include deposits referred to as tar sands; probably little natural asphalt is included in the production figures.

California production statistics consider heavy oil to include all petroleum with gravities less than 20 API degrees (CCCOP, 1990), thus this category includes any extra heavy oil and natural asphalt that was produced. This definition leaves unclear the fate of $20^{\circ}$ oil, as light is considered to be oil with a gravity greater than $20^{\circ}$ in production statistics used in this paper (CCCOP, 1990).

\section{U.S. Resources of Heavy 0il}

Several recent compilations of U.S. heavy oil resources have shown that California has the most heavy oil in place (Nehring, Hess, and Kamionski, 1983; Meyer, Fulton, and Dietzman, 1984; Kuuskraa and Godec, 1989; Crysdale and Schenk, 1990). Kuuskraa and Godec (1989) estimated that California has 42 billion barrels of heavy oil resource in place; Alaska has 25 billion barrels in place (estimates run as high as 50 billion 
barrels in place for Alaska; T. Collett, pers. comm., 1991); Wyoming has about 5 billion barrels; Texas, Arkansas, and Louisiana each have about 2 billion barrels of heavy oil in place, and several states have minor amounts by comparison. Kuuskraa and Godec (1989) estimated the total U.S. resource of heavy oil to be in the range of 80 to 100 billion barrels (compared to about 500 billion barrels of light oil in place), but they concluded that half of this 80 to 100 billion barrels is not economically recoverable with current secondary or thermal technologies. Furthermore, transportation and environmental problems render the recovery of the Alaskan heavy oils problematic at best in the near future. Until these problems are solved, California remains the most important heavy oil province in the U.S. in terms of amount of resource and the extensive use of secondary and thermal recovery (California Department of Conservation, 1990).

Kuuskraa and Godec (1989) further estimated that about 12 billion barrels of heavy oil had been produced in the U.S. through 1985, and that about 2.8 billion barrels of heavy oil are available as proven reserves. Most of this 2.8 billion barrels of heavy oil will require thermal processes for recovery.

\section{Heavy 0il Production Trends}

Production statistics of heavy oil tabulated by the Conservation Committee of California 0il Producers (1990) from the period 1941 to 1990 show that the daily production of heavy oil for the whole state has increased from about 125,000 barrels a day in 1941 to over 700,000 barrels a day in the period 1985-1990 (Fig. 1), peaking at over 825,000 barrels a day in 1986. Heavy oil surpassed light oil production in 1972, and more heavy oil than light oil has been produced daily since that time. The development and installation of commercial steam injection technology was probably responsible for the large rise in heavy oil production in the period from 1963 to 1967, when production rose from about 300,000 to 500,000 barrels per day. This level of production was remarkably steady until 1981, at which time heavy oil production rose to over 800,000 barrels a day in the period from 1981 to 1986. This jump probably reflects rapid increases in petroleum prices around 1980, which added considerable incentive to produce heavy oil. The price crash of 1986 is probably reflected in the rapid decrease in California petroleum production from 1986 to the present. The production of conventional (light) oil in California peaked in 1954; heavy oil has been the reason for increases in petroleum production since that time (Fig. 1).

As a percentage of the total California daily production, heavy oil rose from about $20 \%$ in 1941 to about $70 \%$ of the daily production in the period from 1985-1990 (Fig. 2). Heavy oil surpassed the 50\% mark in 1972, and production has risen rapidly to today's mark of $70 \%$ of daily California production.

Production statistics allow heavy oil production (as listed in the CCCOP tables) to be approximately separated into extra heavy and heavy (Fig. 3). The curve on Figure 3 traces the production of oil with a gravity of less than 12 API degrees, which is slightly higher than the definition of less than 10 API degrees for extra heavy oil. The curve demonstrates that, as a percentage of total heavy oil, extra-heavy oil production dropped during the period from 1960 to 1989, from a high of over $14 \%$ in 1960 to about $1 \%$ of the daily production of heavy oil in 1989 . This drop in production of extra heavy oil may be due to a combination of 
factors, including tremendous increases in production of oil in the 10 to 20 API degree range from fields in the San Joaquin Valley such as Kern River, South Belridge, and Midway-Sunset, and possible termination of expensive steam projects in extra heavy oil fields.

\section{Thermally Enhanced 0il Recovery}

Thermal stimulation of reservoirs in California is common due to the predominance of heavy oil. Thermal stimulation, generally steaming, provides heat to the petroleum which reduces the viscosity and allows the oil to be mobilized and recovered (Carrigy, 1983). Compilations of production statistics by the CCCOP (1990) indicate that, in the period from 1975 to 1989, the percentage of the total California daily petroleum production recovered by steaming increased from about 26\% in 1975 to about $50 \%$ in 1988 and 1989 (Fig. 4). Fields with large-scale thermal projects in heavy oil reservoirs include Midway-Sunset, Kern River, and South Belridge, all in the San Joaquin Basin. This statistic demonstrates the importance of steam-assisted recovery in California, and indicates that the results of thermal (steam) recovery projects need to be examined to determine recovery factors of heavy oil and the potential for reservoir damage due to the introduction of steam into the reservoirs (Hutcheon, 1984). The figure of $50 \%$ is for thermal recovery processes only; when secondary water flooding is included, a total of $64.1 \%$ of all California oil is produced by enhanced methods.

\section{Summary}

Rather than being the fuel of the near future in California, more heavy oil than light oil has been produced daily since 1972, and today accounts for about $70 \%$ of California's total daily petroleum production. As assessments of undiscovered resources are partially based on production statistics, the contribution of heavy oil to California production must be considered. Many of the new field discoveries in California, especially offshore, are heavy oil. Recoveries of heavy oil from a given reservoir may be less than conventional oil, even with thermally assisted recovery (Carrigy, 1983), thus estimates of recoverable oil need to be considered in the context of heavy oil production statistics in California. 


\section{References}

California Department of Conservation, 1990, 75th Annual Report of the State 0il and Gas Supervisor - 1989: California Department of Conservation, Division of $0 i l$ and Gas, Publication No. PR06, Sacramento, California, 159 p.

Carrigy, M.A., 1983, Thermal recovery from tar sands: Journal of Petroleum Technology, v. 35, p. 2149-2157.

Conservation Committee of California 0il Producers, 1990, Annual review of California oil and gas production - 1989: Conservation Committee of California 0il Producers, Los Angeles, California, chapter paginated.

Crysdale, B.L., and Schenk, C.J., 1990, Heavy oil resources of the United States: U.S. Geological Survey Bulletin 1885, 127 p.

Hutcheon, I., 1984, A review of artificial diagenesis during thermally enhanced recovery, in McDonald, D.A., and Surdam, R.C., eds., Clastic Diagenesis: American Association of Petroleum Geologists Memoir No. 37, p. 413-429.

Kuuskraa, V.A., and Godec, M.L., 1989, Characteristics and potential of U.S. heavy oil resources, in Meyer, R.F., and Wiggins, E.J., eds., The Fourth UNITAR/UNDP International Conference on Heavy Crude and Tar Sands, Volume 2: Alberta 0il Sands Technology and Research Authority, Edmonton, Alberta, Canada, p. 257-276.

Meyer, R.F., and de Witt, W., 1990, Definitions and world resources of natural bitumens: U.S. Geological Survey Bulletin 1944, 14 p.

Meyer, R.F., Fulton, P.A., and Dietzman, W.D., 1984, A preliminary estimate of world heavy crude oil and bitumen resources, in Meyer, R.F., Wynn, J.C., and 0lson, J.C., eds., The Future of Heavy Crude and Tar Sands: UNITAR/UNDP Second International Conference, Caracas, Venezeula: McGraw-Hill, Inc., New York, p. 97-158.

Nehring, R., Hess, R., and Kamionski, M., 1983, The heavy oil resources of the United States: Rand Corporation Report R-2946-D0E prepared for the U.S. Department of Energy, 143 p. 


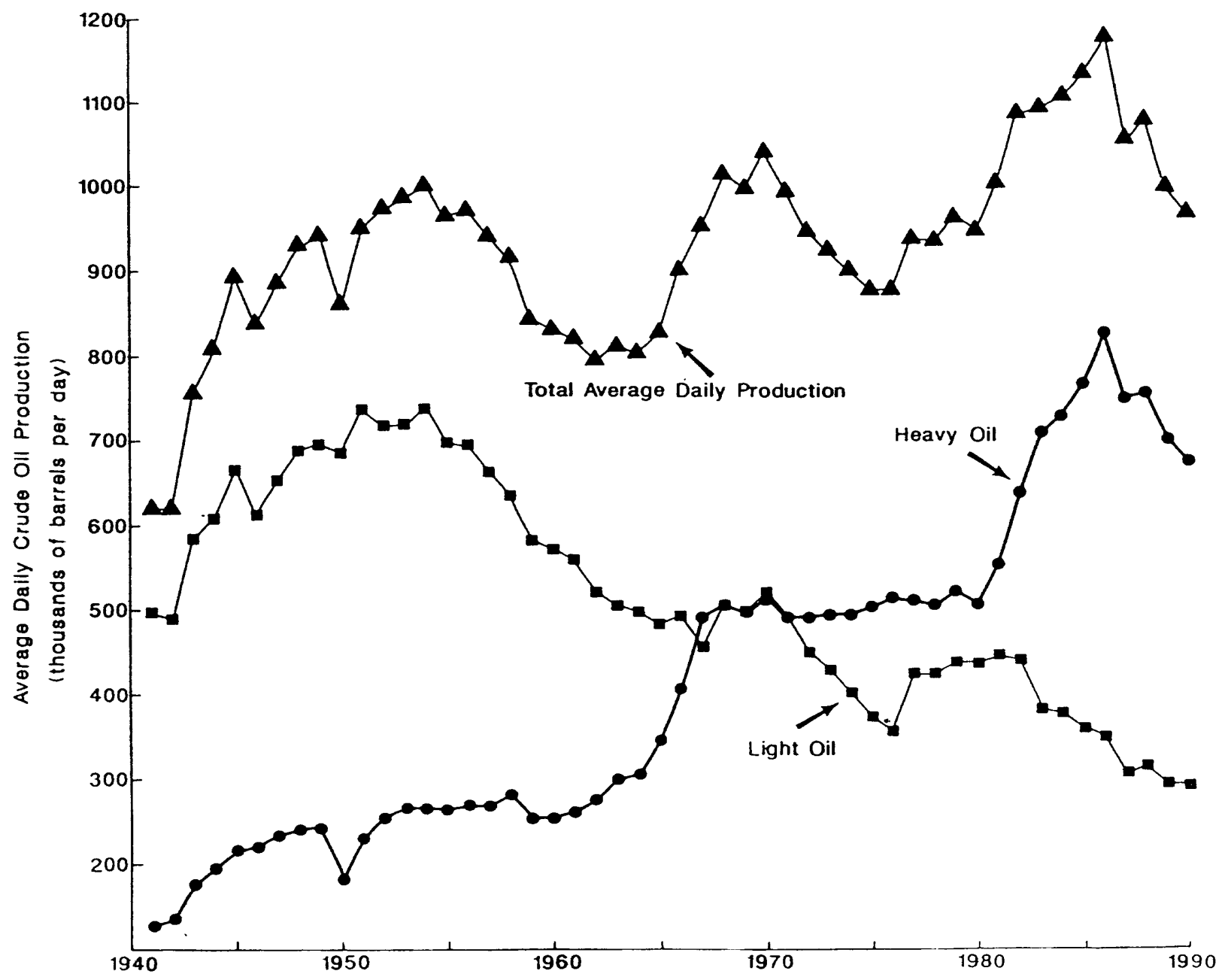

Figure 1. Average daily production of petroleum in California from 1941 to 1990 , in thousands of barrels. Triangles are total daily petroleum production; squares represent daily light oil production; circles are heavy oil production (gravities less than 20 API degrees). Daily petroleum production of light oil peaked at over 700,000 barrels/day in 1954, and has declined to about 300,000 barrels/day in 1990 . Heavy oil production remained below about 300,000 barrels/day from 1941 until about 1963; from 1963 to 1967 heavy oil production increased rapidly to about 500,000 barrels/day, probably reflecting a refinement and commercial application of steam recovery processes. Heavy oil production remained at about 500,000 barrels/day until 1981; from 1981 to 1986 heavy oil production increased rapidly to over 800,000 barrels/day, probably reflecting the rapid increases in the price of petroleum during the early part of that period. The post-1986 oil price crash is reflected in the decline of petroleum production since 1986. Note that since 1972 heavy oil has dominated daily production of petroleum in California. Heavy oil production since 1963 has been responsible for offsetting the precipitous decline in the production of light oil. Heavy oil production figures include fields in the Federal OCS. Data from Conservation Committee of California 0il Producers (1990). 


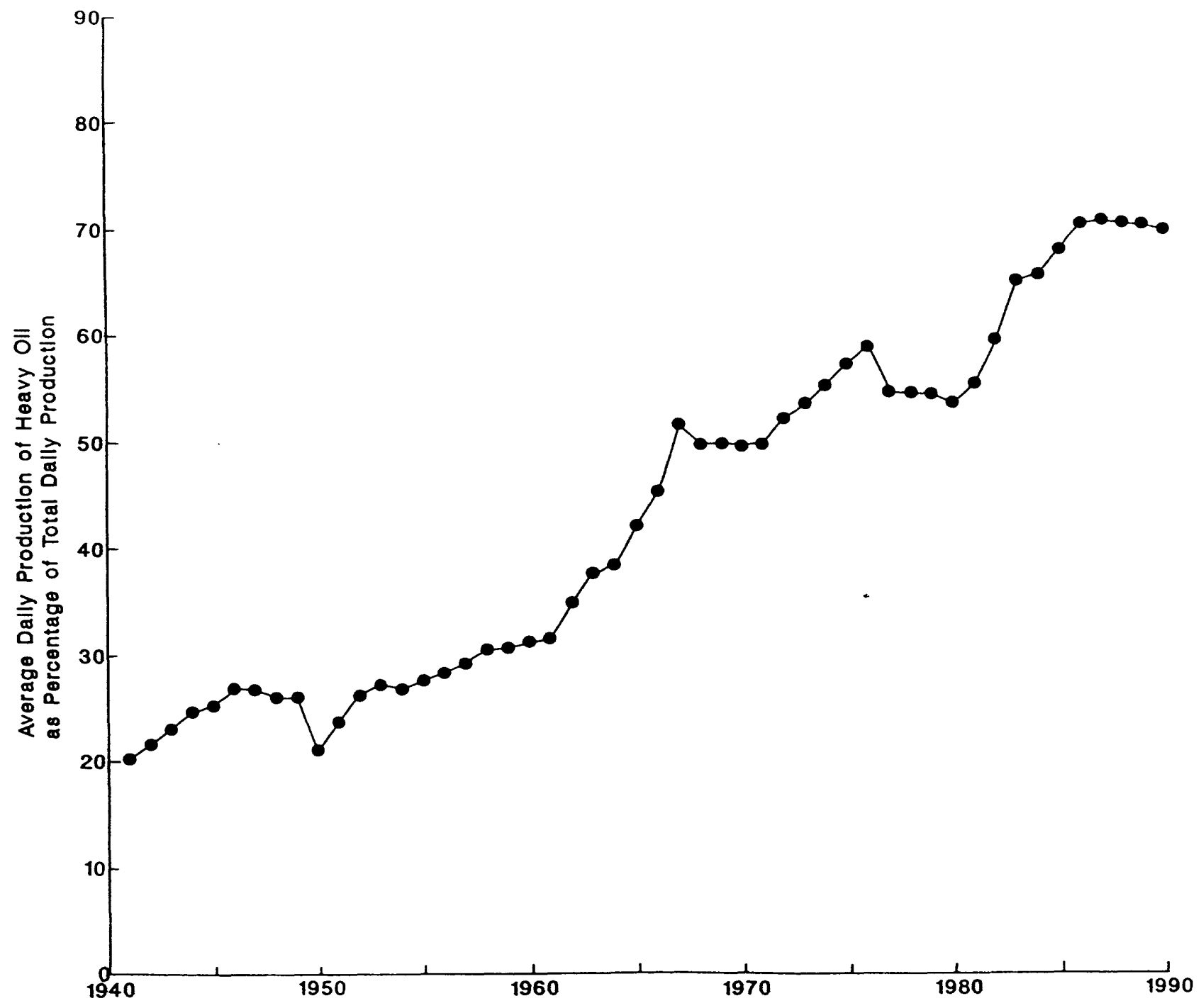

Figure 2. Percentage of average daily petroleum production in California that is heavy oil, from 1941 to 1990 . Until 1958 heavy oil production was less than $30 \%$ of daily California production. The daily production percentage increased to $51 \%$ by 1967 , and was slightly less than $50 \%$ until 1972, After 1972, heavy oil increased from 52\% to today's value of about $70 \%$ of the total daily petroleum production in California. Data from Conservation Committee of California 0il Producers (1990). 


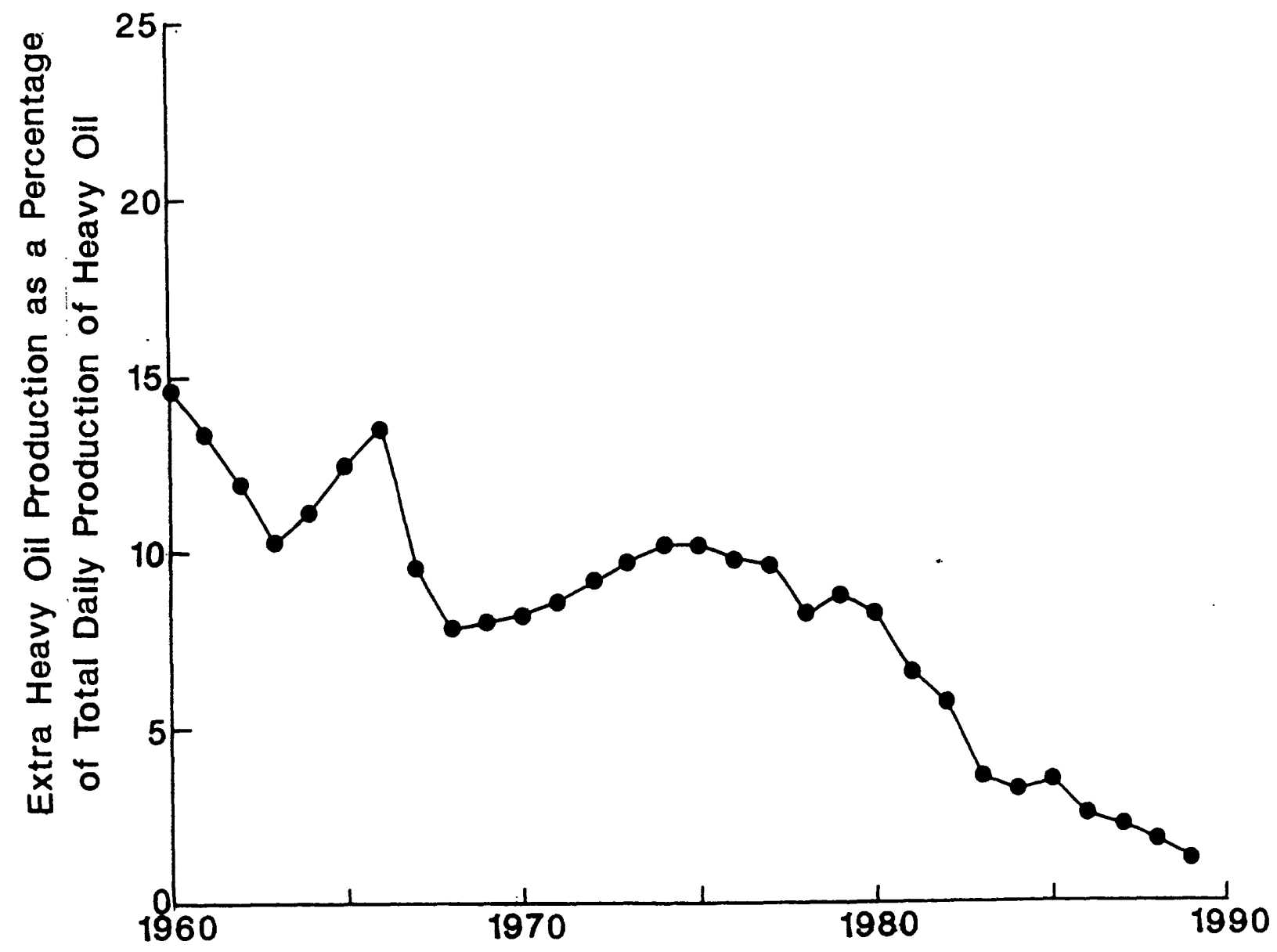

Figure 3. Approximate percentage of heavy oil production in California that can be approximately classified as extra heavy oil, 1960 to 1989.

Production statistics compiled by the CCCOP do not have a break at 10 API degrees, but rather have a break at less than 12 API degrees, making the percentage of extra heavy oil only an approximation. With minor fluctuation, production of extra heavy oil in California has declined with time, from a high of about $14 \%$ in 1960 , to $1 \%$ of total heavy oil production in 1989. Data from Conservation Committee of California 0il Producers (1990). 


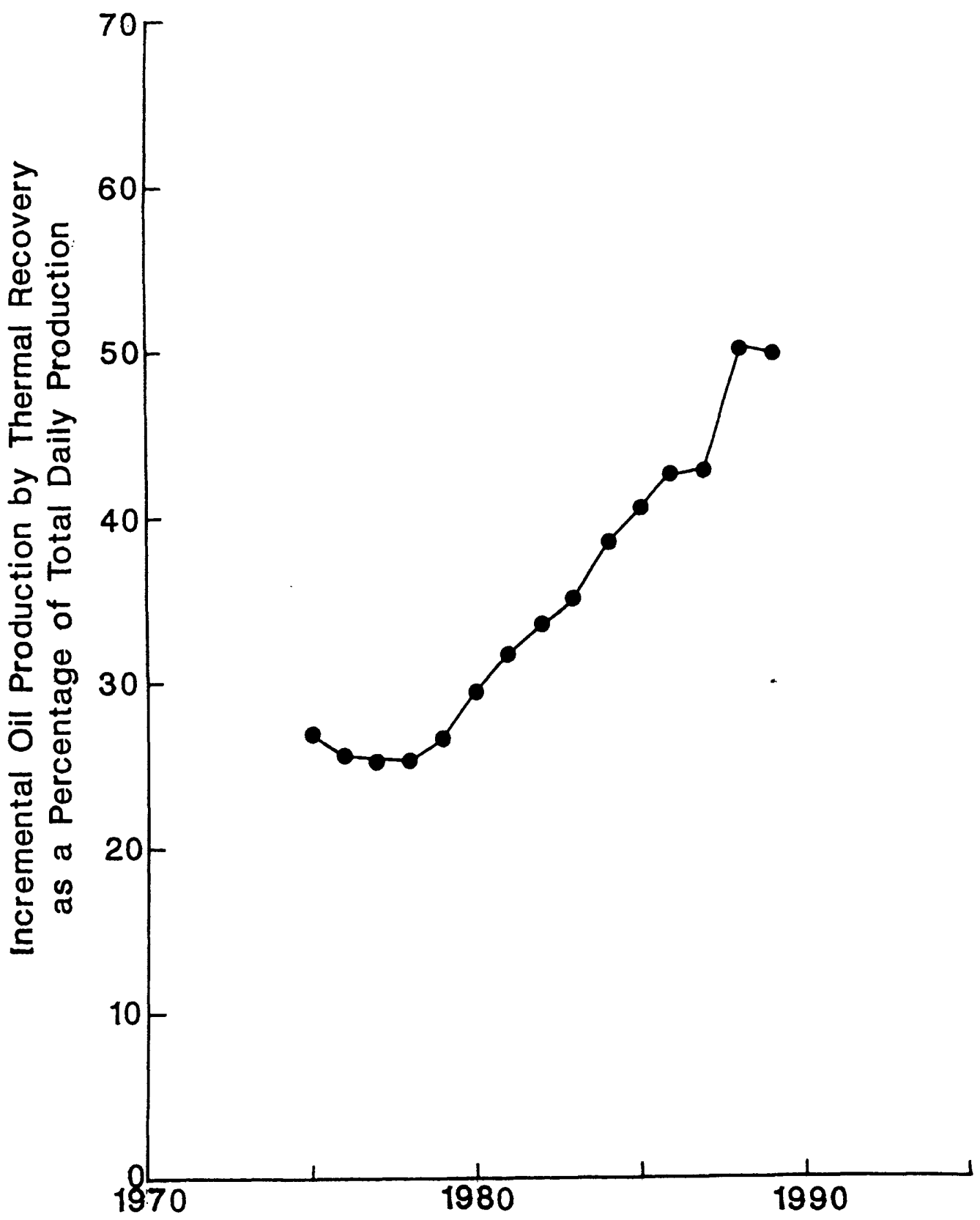

Figure 4. Incremental oil production by thermal processes as a percentage of the state daily production, 1975 to 1989. The "incremental" production increases are those increases calculated to be above projected production declines. Since 1979 state production has increasingly been a function of thermal recovery processes; by 1989 50\% of the total California daily production was thermally assisted (Conservation Committee of California 0il Producers, 1990), up from 26\% in 1975. 